\title{
MINIMALLY INVASIVE LATERAL RETROPLEURAL APPROACH TO THE THORACOLUMBAR JUNCTION - REVIEW \& EXPERIENCE
}

\author{
ACESSO LATERAL E RETROPLEURAL MINIMAMENTE INVASIVO À JUNÇÃO TORACOLOMBAR - \\ REVISÃO E EXPERIÊNCIA
}

\author{
ACCESO LATERAL Y RETROPLEURAL MÍNIMAMENTE INVASIVO A LA JUNCIÓN \\ TORACOLUMBAR - REVISIÓN Y EXPERIENCIA
}

Cristiano Magalhães Menezes, ${ }^{1,2}$ Felipe Miranda Mendonça Fernandes, ${ }^{1}$ André de Olivelra Arruda, ${ }^{1,2}$ Mário Leite Bringel ${ }^{1}$

1. Instituto Columna, Belo Horizonte, MG, Brazil.

2. Hospital Vera Cruz - HVC, Belo Horizonte, MG, Brazil.

\begin{abstract}
Objective: To describe the minimally invasive technique for the lateral retropleural approach to the thoracolumbar spine and its viability in several affections of the region, demonstrating its indications, potential advantages, and necessary precautions, with an emphasis on the local anatomy, especially the diaphragm. Methods: After a review of the literature, the initial experience of the Service is reported, comparing it to the published results. The surgical technique used is described with emphasis on the surgical anatomy of the diaphragm. Results: The minimally invasive lateral retropleural approach to the thoracolumbar junction with the application of an expandable tubular retractor was described step-by-step in this study, with emphasis on the crucial points of technical execution, such as preoperative planning, access to the retropleural plane, and an orthogonal approach for adequate discectomy and/or corpectomy and subsequent implant placement. It can be used in the treatment of deformities, degenerative diseases, trauma, tumors, and infections and it allows for adequate interbody arthrodesis fusion rates associated with a smaller skin incision and less soft tissue damage, blood loss, and postoperative pain. Thus, it results in better postoperative mobility and a shorter hospital stay, which can also be observed in the data from initial experience of this Service. Conclusions: The minimally invasive technique for the lateral retropleural approach to the thoracolumbar spine with the application of an expandable tubular retractor was shown to be promising and safe for the treatment of several spinal diseases despite the complex and challenging local anatomy and it presents advantages over the morbidity rates observed in the traditional approach. Level of evidence IV; Case series.
\end{abstract}

Keywords: Minimally Invasive Surgical Procedures; Spine; Pleural Cavity.

\section{RESUMO}

Objetivo: Descrever a técnica minimamente invasiva para acesso lateral retropleural à coluna toracolombar e sua viabilidade em diversas afecções da região, demonstrando suas indicações, vantagens em potencial e cuidados necessários, com destaque para a anatomia local, especialmente o diafragma. Métodos: Após revisão da literatura, relata-se a experiência inicial do serviço, comparando-a aos resultados publicados. Descreve-se a técnica cirúrgica empregada, com ênfase na anatomia cirúrgica do diafragma. Resultados: A técnica de acesso lateral retropleural minimamente invasivo à junção toracolombar, com aplicação de retrator tubular expansível, foi descrita passo a passo neste estudo, com destaque de pontos cruciais de execução técnica, tais como planejamento pré-operatório, acesso ao plano retropleural e abordagem ortogonal para discectomia e/ou corpectomia adequadas e posterior colocação de implante. Ela pode ser usada no tratamento de deformidades, doenças degenerativas, trauma, tumor e infecções e possibilita taxas adequadas de fusão pela artrodese intersomática associada à menor incisão de pele, dano aos tecidos moles, perda sanguínea e dor pós-operatória. Resulta, assim, em melhor mobilidade pós-cirúrgica e menor período de internação hospitalar, o que pode ser observado também nos dados da experiência inicial do Serviço. Conclusões: A técnica de acesso lateral retropleural minimamente invasivo à junção toracolombar com aplicação de retrator tubular expansível mostra-se promissora e segura para tratamento de diversas doenças da coluna, apesar da anatomia local complexa e desafiadora e apresenta vantagens diante da morbidade decorrente da abordagem tradicional. Nível de evidência: IV; Série de casos.

Descritores: Procedimentos Cirúrgicos Minimamente Invasivos; Coluna Vertebral; Cavidade Pleural.

\section{RESUMEN}

Objetivo: Describir la técnica mínimamente invasiva para acceso lateral retropleural a la columna toracolumbar y su viabilidad en diversas afecciones de la región, demostrando sus indicaciones, ventajas en potencial y cuidados necesarios, destacando la anatomía local, especialmente el diafragma. Métodos: Después de revisión de la literatura, se relata la experiencia del Servicio, comparándola a los resultados publicados. Se describe la técnica quirúrgica empleada, con énfasis en la anatomía quirúrgica del diafragma. Resultados: La técnica de acceso lateral retropleural mínimamente invasivo a la junción toracolumbar, con aplicación de retractor tubular expansible, fue descrita paso a paso en este estudio, con destaque de puntos cruciales de ejecución técnica, tales como planificación preoperatoria, acceso al plano retropleural y abordaje ortogonal para discectomía y/o corpectomía adecuadas y posterior colocación de implante. La misma puede ser usada en el tratamiento de deformidades, enfermedades degenerativas, trauma, tumor e infecciones y posibilita tasas adecuadas de 
fusión por artrodesis intersomática asociada a la menor incisión de piel, daño a los tejidos blandos, pérdida sanguínea y dolor postoperatorio. Resulta, así, en mejor movilidad postquirúrgica y menor período de internación hospitalaria, lo que puede ser observado también en los datos de la experiencia inicial del Servicio. Conclusiones: La técnica de acceso lateral retropleural mínimamente invasivo a la junción toracolumbar con aplicación de retractor tubular expansible se muestra prometedora y segura para tratamiento de diversas enfermedades de la columna, a pesar de la anatomía local compleja y difícil, y presenta ventajas delante de la morbilidad del abordaje tradicional. Nivel de evidencia IV; Serie de casos.

Descriptores: Procedimientos Quirúrgicos Mínimamente Invasivos; Columna Vertebral; Cavidad Pleural.

\section{INTRODUCTION}

The minimally invasive lateral retropleural approach to the thoracolumbar junction has been increasingly more indicated in the treatment of various situations, such as deformities, tumors, traumatic and degenerative conditions, and infections. ${ }^{1-4}$ This is a result of the good outcomes observed with the use of the technique, capable of promoting adequate rates of interbody fusion while benefiting from smaller surgical incisions, reduced blood loss, and shorter periods of hospitalization. ${ }^{2-5}$ The development of the technique allowed not only arthrodesis to be performed, but also decompression under direct visualization of the neural elements in their ventral portion, corpectomies, restoration of vertebral height, and improved spinal alignment and stabilization.

Understanding the anatomy of the thoracolumbar junction (T1L1) is complex and challenging to spine surgeons, highlighting the presence of the diaphragm - a structure that divides the thoracic and abdominal cavities anatomically. ${ }^{2,6-8}$ The use of an expandable tubular device, capable of creating a corridor for the direct visualization of the antero-lateral portion of the spine in the thoracolumbar junction, thus avoiding the complications of an open thoracophrenolombotomy seems to be the key to reduce the morbidity related to surgical access and deal with the nuances of the regional anatomy. For this, it is crucial to keep surgical dissection out of the pleural cavity, using an extracavitary plan in order to safely mobilize the diaphragm. ${ }^{2}$ Retropleural access is achieved by creating a plane between the parietal pleura and the internal surface of the rib below the initial incision, with the diaphragm and pleura retracted and dissected by anterior approach, ${ }^{6}$ which allows lateral access to the vertebral bodies and discs, as well as to the ventral dural sac for decompression.

The objective of this study is to describe the minimally invasive lateral retropleural approach to the thoracolumbar junction using an expandable tubular retractor, as well as its indications, contraindications, and complications. The results of the initial experience of the Spinal Surgery Service of the Instituto Columna/ HVC, Belo Horizonte, MG, will be presented.

\section{METHODS}

This is a retrospective study based on a free review of the literature and a staged description of the surgical technique.

The initial experience of the Service (Instituto Columna/ Hospital Vera Cruz, Belo Horizonte, MG) was also reported, with the presentation of the preliminary results of patients operated by the technique in question. After the patients signed the Informed Consent Form and the study was approved by the Institutional Review Board as record no. 1.301.609, the collection and organization of the data for publication began.

\section{Minimally invasive lateral retropleural approach to the thoraco- lumbar junction}

\section{Indications and contraindications}

The selection of the most appropriate access for the condition of each patient/disease to be treated can be difficult and challenging, but also decisive for the success of the surgical treatment.

Minimally invasive lateral retropleural access to the thoracolumbar junction can be indicated in the treatment of degenerative diseases, infections, tumors, and traumas.
In the various indications, this access is used in association with open or percutaneous pedicular instrumentation or with anterior plates, both in cases of interbody arthrodesis and after corpectomies. ${ }^{4}$

The same idea can guide corpectomies in patients with spinal tumors, in the context of medullary compression or pathological fractures, aiming for stabilization, spinal cord decompression, pain control, and improved quality of life as part of palliative treatment, especially in vertebral metastases. ${ }^{9,10}$ Excision of the intracanal or intramedullary tumor lesion is also possible, through access to the spinal canal.

Cases of spondylodiscitis in the thoracolumbar junction or low thoracic spine can also be treated by means of this access, with the objective of local debridement to cure the infectious process, as well as favoring arthrodesis and preventing the emergence of post-infectious deformities. ${ }^{10-12}$

While still in the preoperative period, the presence of contraindications relative to the technique in question, capable of compromising therapeutic success, have to be assessed. They include anomalies in the vascular anatomy (lateralized vessels in patients with deformities and rotation of the vertebral body, or positioning of the Adamkiewicz artery in the access path), vascular diseases, retroperitoneal or retropleural scarring from previous surgery, intense pleural inflammatory reaction secondary to infections (e.g. tuberculosis), when direct posterior decompression is necessary, the presence of bone structures (such as syndesmophytes) capable of limiting access, patients with high BMI or with thoracic or pulmonary abnormalities. It is essential to evaluate the effects of the curvature and rotation of the spine on vascular and visceral anatomy for greater safety. ${ }^{13}$

\section{Preoperative planning}

A proper indication of lateral retropleural access should begin with the identification of those patients most likely to benefit from the technique, but it should also take the surgeon's experience and ability to perform it into account.

Initial planning requires special attention to the patient's previous medical history as regards characteristics or facts that could hinder an anterolateral spinal approach, as well as a thorough evaluation of anteroposterior (AP) and lateral radiographs and magnetic resonance images focused on preventing complications.

In the operating room it is important to properly position the radioscope monitor and the neuromonitorization equipment to allow the image intensifier to move freely as needed and to ensure that they are easily viewed by the surgeon and their team. Here, the familiarity of the surgeon with radioscopic images obtained in the lateral position is essential to prevent complication resulting from poor positioning of retractors and spacers

Standard intubation may be performed at the time of general anesthesia and the use of a double-lumen tube is not routine. Reducing the volume of oxygen flow facilitates retropleural dissection. ${ }^{3}$

\section{Positioning of the patient}

The patient should be positioned in lateral decubitus, usually right, (Figure 1) with the left side to be accessed facing up and approximately $10 \mathrm{~cm}$ from the edge of the operating table. Head support is used, allowing the anesthetist free handling of the airways. A cushion is positioned under the armpit in contact with the operating table to protect the axillary plexus. The lower limbs do not need to be kept flexed, positioning cushions in the areas of contact 
of the common fibular nerve and other bony prominences. At this time, images of the spine should be obtained by the intensifier in true AP and lateral views.

Next, the parts of the patient's body are fixed to the operating table with adhesive tape to prevent their movement during the surgery, which could cause rotation of the spine and erroneous access with poor positioning of the implants and/or inadvertent injuries to the adjacent structures, such as vessels and viscera. Adhesive tape must be attached to the thoracic region at the level of the nipples (with previous protection), at the height of the iliac crest, and on the lower limbs. Tape is also passed from the hips to the knees and from the knees to the ankles.

Two pillows are placed between the patient's arms, leaving them free for the administration of intravenous drugs.

The table break is not needed to increase the distance between the lower edge of the ribs and the iliac crest.

The flexible arm of the expandable tubular retractor should be positioned posteriorly at the level of the patient's scapula.

\section{Surgical technique}

Surgery begins with marking the skin, which will serve as a guide for a proper incision. At this time, an image should be obtained in true profile to verify and mark the level to be operated with the help of a guide wire or a marker. (Figure 2) The projection of the pathways of the anterior (ALL) and posterior (PLL) longitudinal ligaments onto the skin is delimited and then the guide wire is used along the rib corresponding to the desired level, extending posteriorly about $20 \%$. (Figure 3) Resection of the rib may be necessary in cases where it is superimposed on the level to be operated. In most cases, the rib used as a reference for the disc space to be accessed corresponds to the one that is two levels above the desired level; namely, the tenth rib corresponds to level T12L1 and the ninth is used for T11T12.

A skin incision of around $6 \mathrm{~cm}$ (Figure 4) should be made with soft tissue dissection until the rib (Figure 5) or intercostal space is exposed. At this stage, it is extremely important to review the anatomy of the diaphragm.

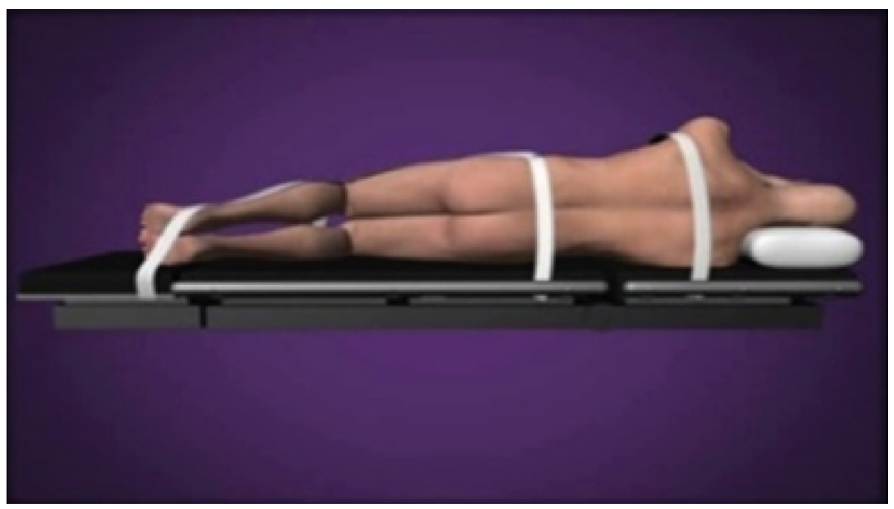

Figure 1. Positioning

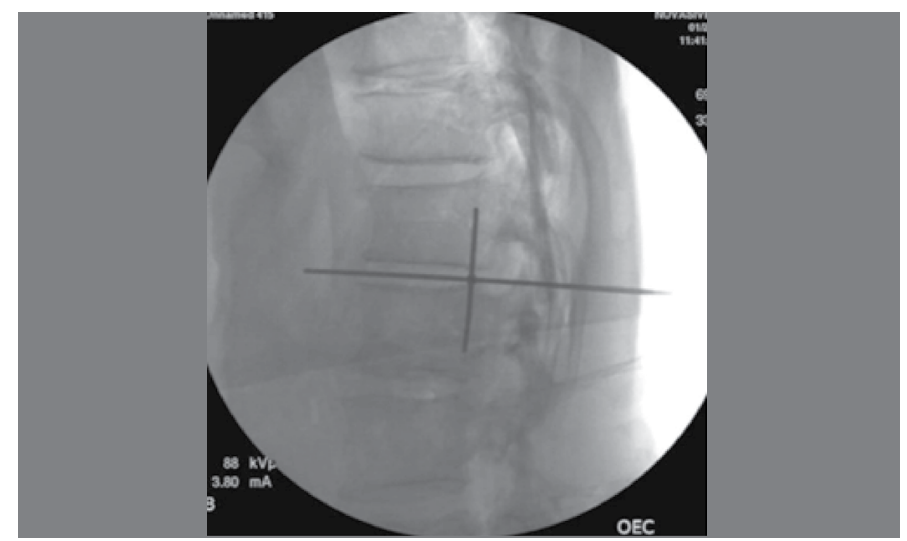

Figure 2. Marking with guide wire.

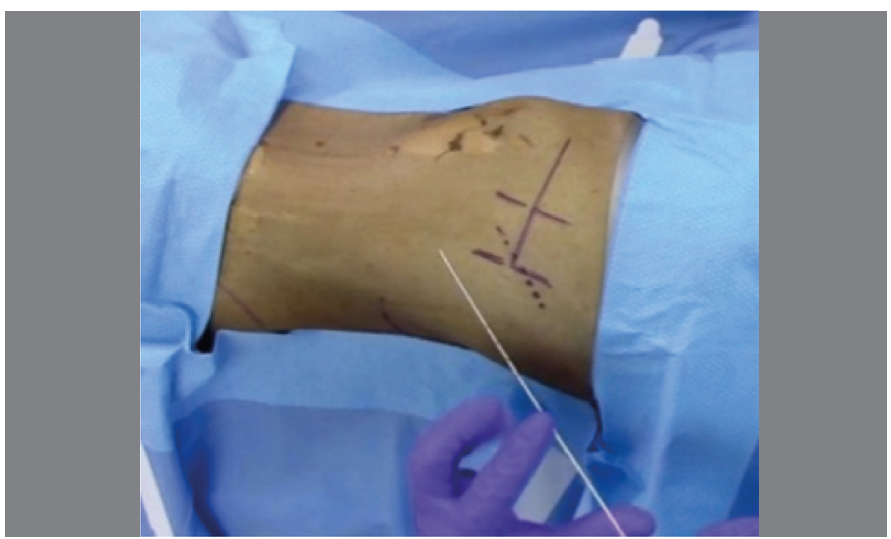

Figure 3. Marking of the skin.

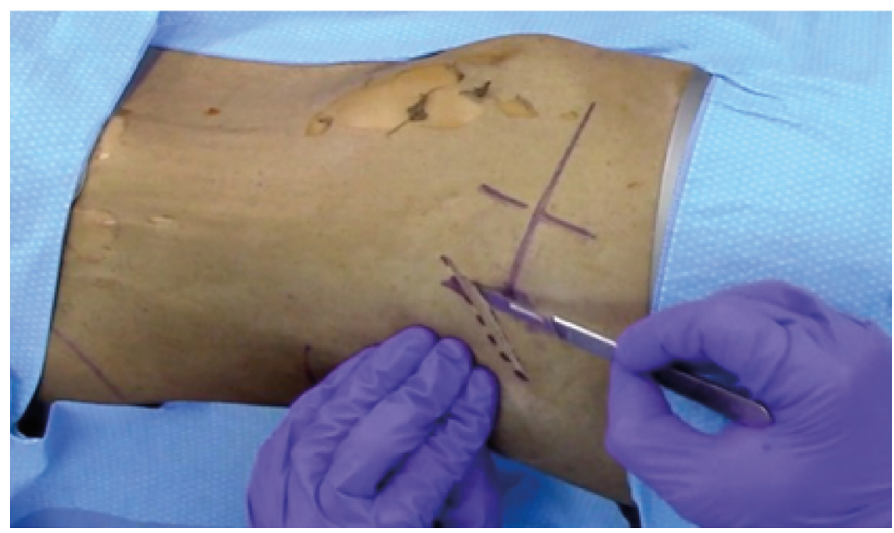

Figure 4. Incision of the skin.

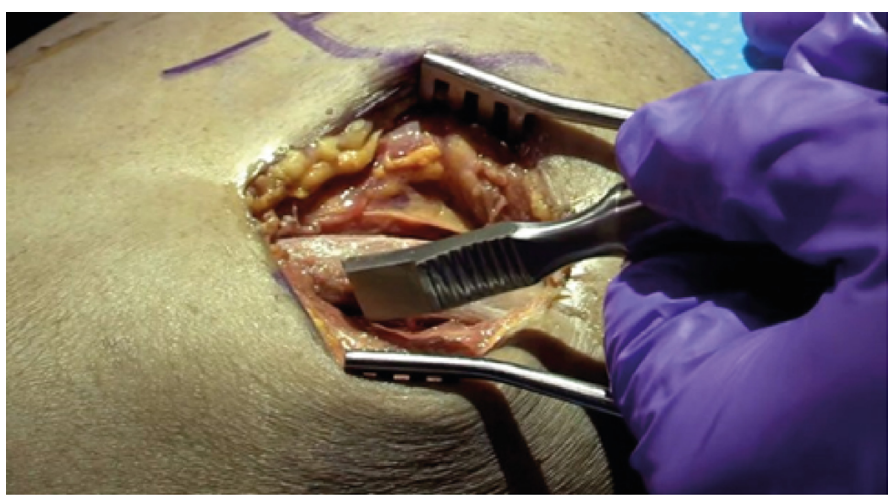

Figure 5. Skeletalization of the rib.

The diaphragm is a musculotendinous layer between the thoracic and abdominal cavities with sternal or anterior, costal, or lateral, and lumbar or posterior insertions. The sternal insertion is not involved in this approach, unlike the costal and lumbar insertions, which are crucial. The costal or lateral insertion occurs medially at the ninth and tenth ribs, while the posterolateral insertion occurs at the eleventh and twelfth ribs. Posteriorly, the diaphragm has two arcuate ligaments, one on each side: the lateral arching over the quadratus lumborum muscle and the medial arching over the origin of the psoas muscle. The point of intersection of the insertion of the arcuate ligaments corresponds to the transverse process of L1.2,6-9

Initially, to access the thoracolumbar junction, the extracelomic space must be preserved, developing a retropleural plane and mobilizing the diaphragm of its costal and lumbar insertions. Dissection of the costal muscle layer begins above the desired space. About $5 \mathrm{~cm}$ of the most posterior possible portion of the rib is resected, protecting its vascular nerve bundle that is found in the lower portion. (Figure 6) The rib bone is then saved for use in bone grafting. 
(Figure 7) Then, the dissection must follow a thin fascia that is found before the parietal pleura, the endothoracic fascia. (Figure 8) Care must be taken to release the parietal pleura and the diaphragm from the ventral and posterior surface of the rib. For this purpose, blunt-tip instruments should be used (and never electrocauterization), given the risk of injury to the neurovascular fascia and pleura. The parietal pleura is then released (digital dissection), introducing the index finger into the posterior section of the remaining rib and performing cranial-caudal sweeping movements as the finger advances in the direction of the spine. Upon reaching it, the L1 transverse process is palpated to locate the insertion of the arcuate ligament (Figure 9) and release it, thus permitting access to the spine in the space created connecting the retroperitoneum and the retropleura. With the aid of the finger, the dilator is inserted, moving the diaphragm and its thoracic contents away up to the surface of the psoas muscle when it is below $L 1$, or directly over the spine when it is above $L 1$. After fitting the first dilator and neuromonitorization, a Kirschner

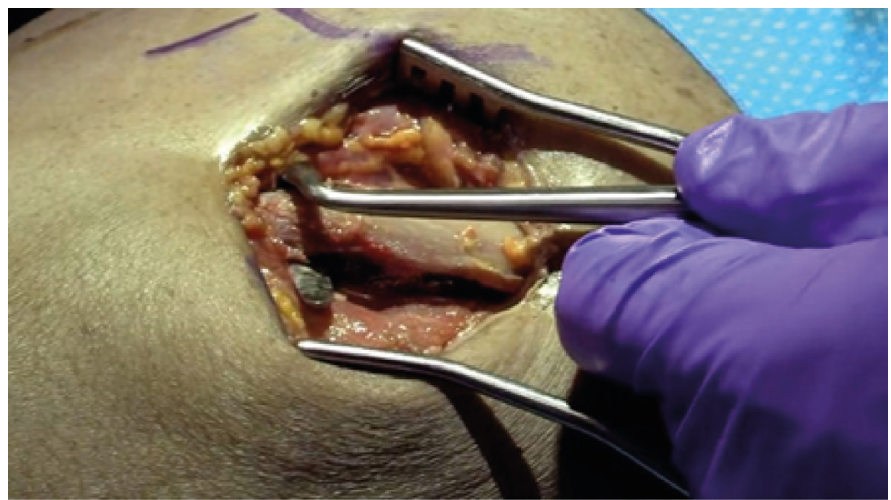

Figure 6. Inferior dissection of the rib.

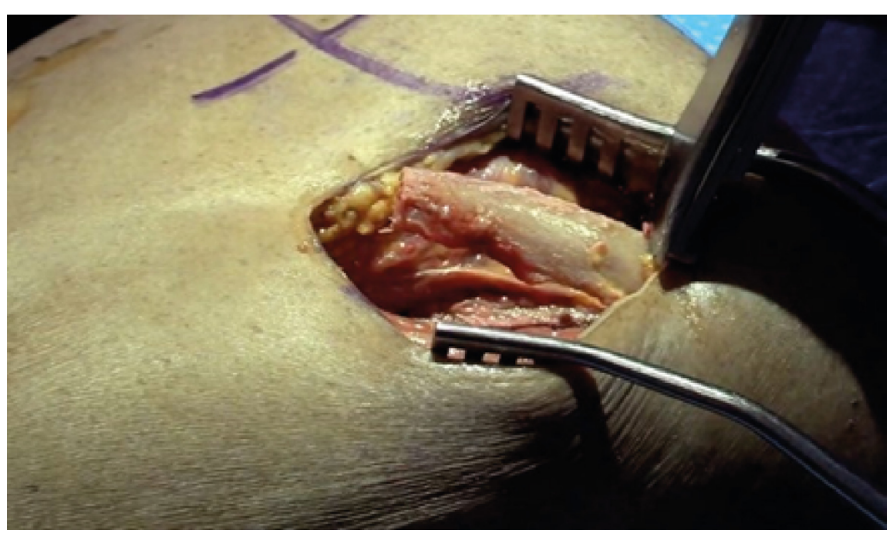

Figure 7. Resection of the rib.

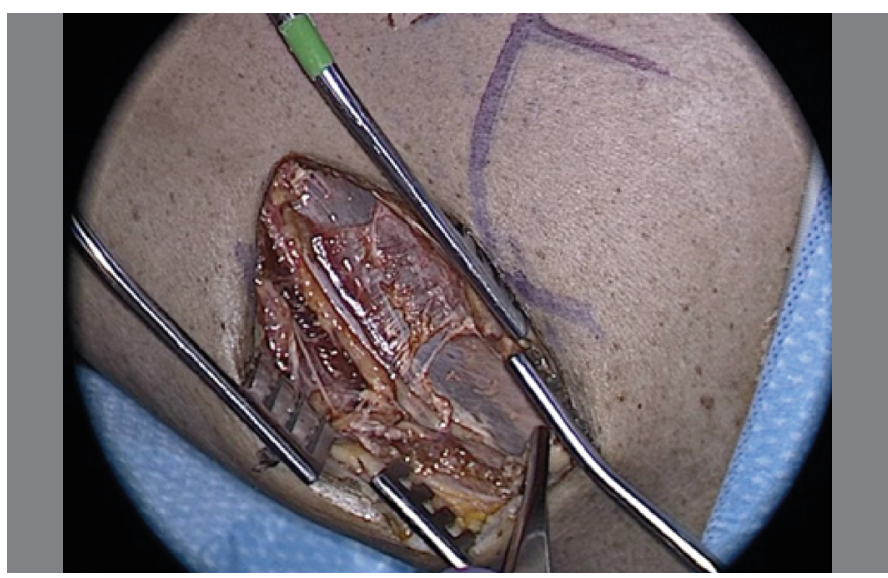

Figure 8. Parietal pleura and endothoracic fascia, after removal of the rib. wire must be inserted in the posterior third of the disc space, using fluoroscopy to confirm its proper positioning.

Then, the next dilators are inserted and the length of the retractor blade from the first dilator is measured (adding $10 \mathrm{~mm}$ from the skin level). The dilator blades are moistened with saline solution as they are inserted, preventing damage to the soft parts up to the lateral surface of the disc. There, the retractor progresses guided by the dilator and with AP and lateral images, confirming that there has been no rotation of the spine. (Figure 10) Next, the retractor is attached to the flexible arm previously fixed to the operating table. While one hand presses down on the retractor, the other squeezes the system until it makes a "click" sound. The light source should be positioned half of the distance from the blades. In the event that the retractor moves, the shim can be used to fix it. The retractor must be opened by turning the handle located on the upper part and pressing down with one of the hands until four "clicks" are heard. The lateral plastic shim that attaches to the retractor blades can be useful for moving tissues that may invade the field out of the way.

The final objective is to obtain a free corridor (Figure 11) for the execution of the planned procedure, such as discectomy, ventral decompression of the spinal cord, or corpectomy, among others.

At the end of the procedure, the retractor and shim are removed under direct visualization, with attention to hemostasis, and closure of the previously divulsed structures proceeds. A bubble test can be conducted to assess possible iatrogenic injury of the parietal pleura. For this, saline solution is added to the retropleural space and the anesthetist is asked to inflate the lungs. If no bubbles appear, the parietal pleura is intact, and a chest tube is not necessary. The intercostal muscles are reapproximated and the serratus and latissimus dorsi muscle layers are closed up to the dermis layer under direct visualization, with sutures at intervals of up to one centimeter. The anesthetist is asked to perform the Valsalva maneuver and observe whether there is any air exiting through

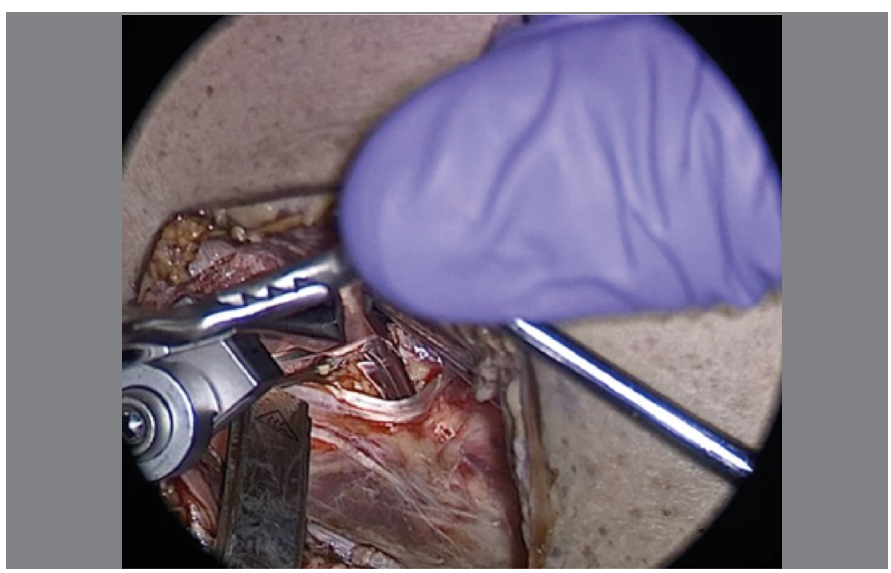

Figure 9. Arcuate ligament.

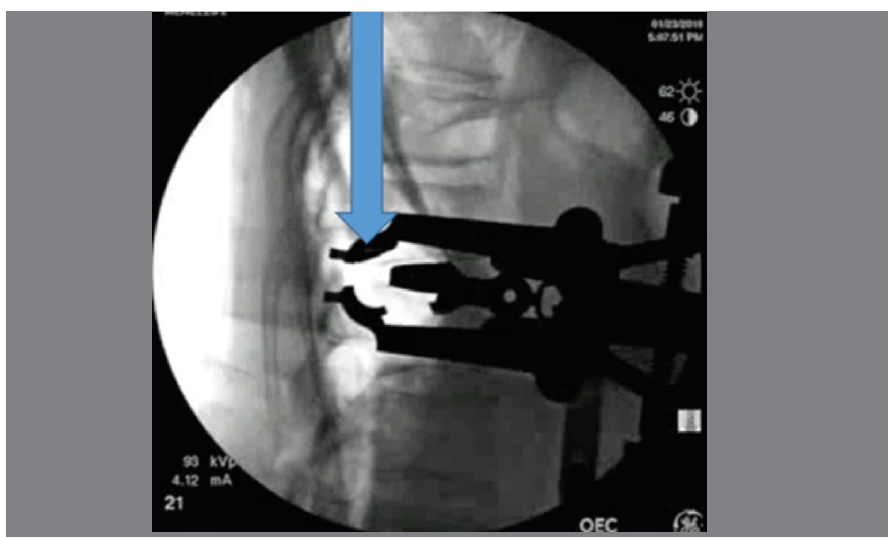

Figure 10. Retractor positioning. Arrow shows the possibility of access to the spinal canal. 
the drain (the outer end of which is immersed in saline solution, which may produce bubbles), which must be pulled and removed after the bubbles have disappeared, proceeding with the closure of the incision.

\section{Postoperative care}

At the end of surgery, the patient is usually sent to the recovery room, from where they will be moved to the nursing unit. Single-level surgeries do not require recovery in the Intensive Care Unit (ICU). Corpectomies, surgeries in oncology patients and/or in those who present neurological deficit should be referred to intensive care.

An oral diet should be approved after the initial recovery period. Analgesics may be necessary in the postoperative period and will be administered according to the demand. Ambulation should be encouraged a few hours after surgery, on the same day.

\section{Prevention of complications}

Careful preoperative planning combined with rigorous monitoring of the peri- and postoperative steps and the surgeon's skill and experience are able to minimize the risks of complications resulting from this technique, which are not frequent.

Special care should be taken to avoid injury to the neurovascular bundle of the 12th rib from electrocauterization. This could lead to pseudo-herniation or denervation of the abdominal wall muscles, considering that the 12th intercostal nerve corresponds to the first branch of the lumbar plexus (subcostal nerve).

Extensive knowledge of the local anatomy is the best form of prevention against inadvertent damage of the pleural structures, with subsequent thoracic violation.

In a pragmatic way, we call attention to the fact that, in patients

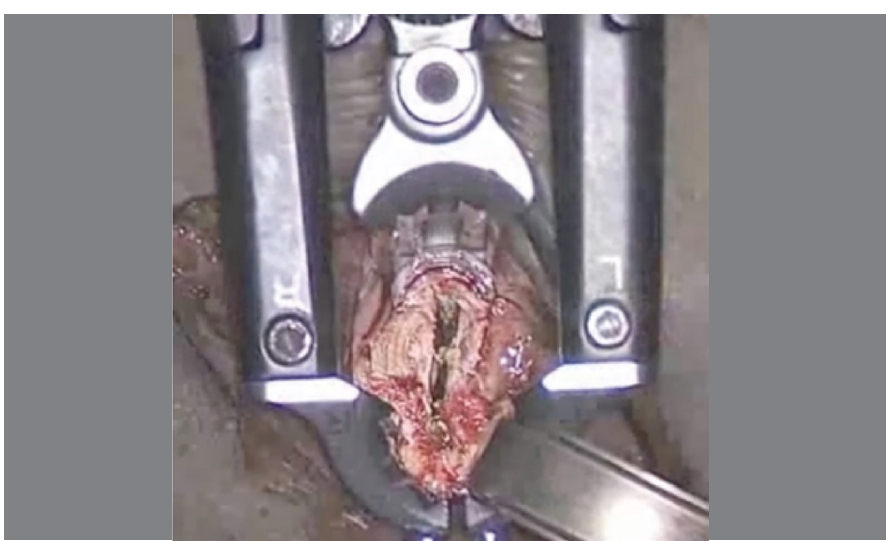

Figure 11. Corridor through the retractor. whose surgical incision occurs below the 12th rib, only the retroperitoneal cavity is invaded, following the principles of the traditional XLIF technique. However, when the incision is made between the 11th and 12th ribs, the transdiaphragmatic retroperitoneal approach is performed, or above the 11th rib, with the retropleural approach, with the need to control both cavities.

\section{RESULTS}

\section{Initial experience of the service}

The initial experience of the service is summarized according to the data shown in Table 1 below:

\section{Clinical Case}

A male patient, 49 years of age, came to the office complaining of imbalance and difficulty walking. In the physical examination he presented signs of thoracic myelopathy, such as ataxic gait, hyperreflexia in the lower limbs, but without sphincter changes. The MR examination showed an extruded disc herniation of T10-T11. (Figure 12) A minimally invasive lateral retropleural approach was chosen to remove the herniated disc and the entire disc component with interbody arthrodesis with cage, lateral plate, and screws. (Figure 13) Adequate decompression of the spinal canal and spinal alignment can be seen in the postoperative image examinations. (Figure 14)

\section{DISCUSSION}

Thoracotomy or thoracophrenolombotomy, previously used to treat diseases of the thoracolumbar transition, are associated with

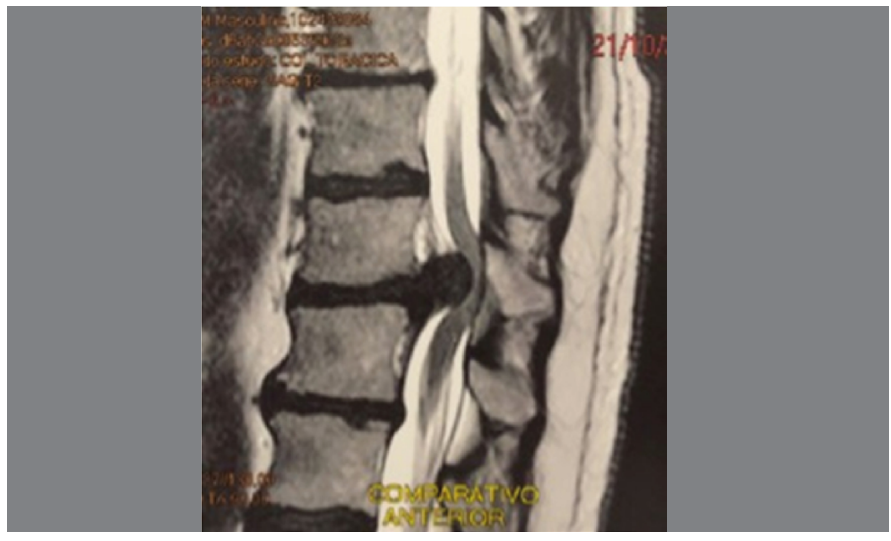

Figure 12. Herniation of disc T10-11. Plate and screws with severe spinal cord compression

Table 1. Description of the characteristics of the cases operated by the minimally invasive retropleural approach to the thoracolumbar junction.

\begin{tabular}{|c|c|c|c|c|c|c|c|}
\hline Case & Sex & Age & Indication & Complications & $\begin{array}{l}\text { VAS } \\
\text { Pre-op }\end{array}$ & $\begin{array}{c}\text { VAS } \\
\text { Post-op }\end{array}$ & Days in the hospital \\
\hline 2 & M & 42 & Degenerative Disc Disease T11T12 & & 7 & 3 & 1 \\
\hline 4 & $\mathrm{~F}$ & 63 & Degenerative Scoliosis XLIF L1L5 & & 8 & 2 & 4 \\
\hline 5 & $\mathrm{~F}$ & 74 & Degenerative Scoliosis XLIF L1L5 & & 8 & 2 & 3 \\
\hline 6 & $\mathrm{M}$ & 48 & Spondylodiscitis T7T8 & & 10 & 0 & 10 \\
\hline 9 & $\mathrm{M}$ & 51 & Degenerative Disc Disease T12L1 & Pleural effusion/ Pneumonia & 8 & 6 & 7 \\
\hline 10 & $\mathrm{M}$ & 49 & Disc herniation T10T11 & & 9 & 1 & 2 \\
\hline 11 & M & 30 & Corpectomy T12 trauma & $\begin{array}{l}\text { Inadvertent thoracic invasion } \\
\text { (pleural injury) } \\
\end{array}$ & 10 & 0 & 3 \\
\hline 12 & $\mathrm{~F}$ & 52 & Adjacent disease L1L2 & & 7 & 3 & 1 \\
\hline
\end{tabular}




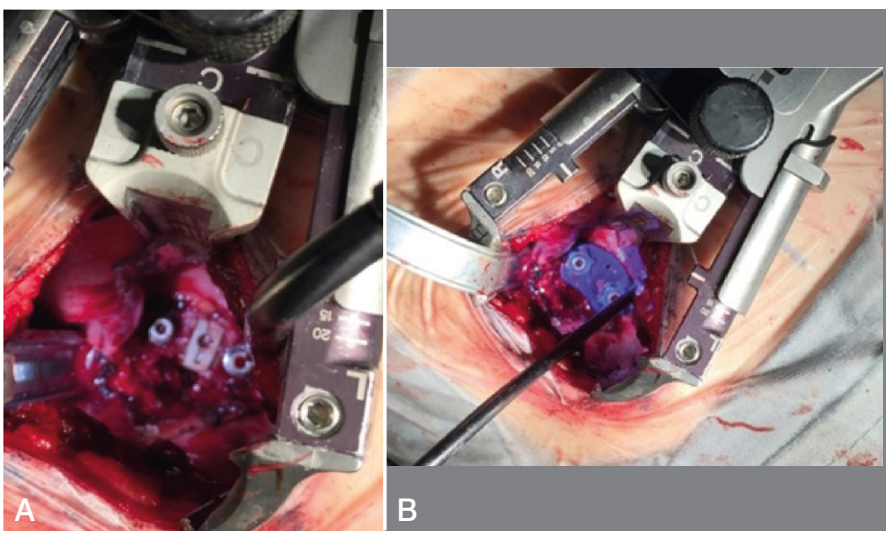

Figure 13. A) Cage; B).

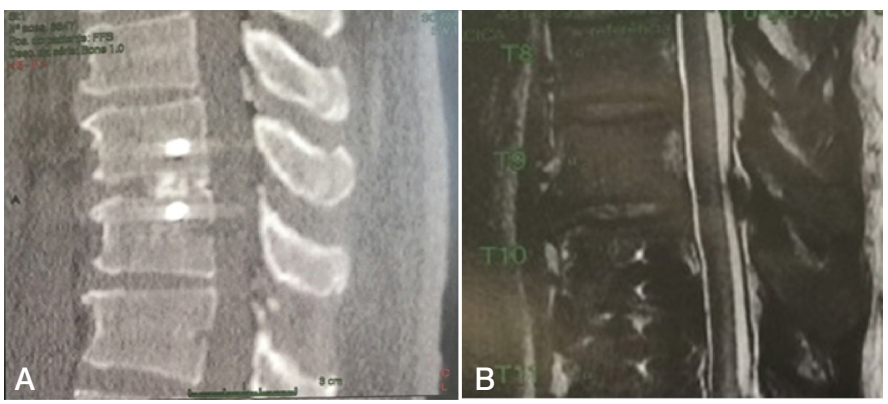

Figure 14. A) CT; B) MRI showing adequate spinal cord decompression and positioning of the implants.

high postoperative morbidity, which translates to pain secondary to the extensive surgical incision and the need for wide muscle dissection; invasion of the rib cage, with the possible reduction of vital pulmonary capacity; need for use of a thoracic drain and its inherent risk of complications; and prolongation of hospital stay. ${ }^{13}$

Minimally invasive lateral retropleural access, in turn, decreases the morbidity associated with open thoracotomy for different reasons: it requires a less extensive surgical incision; it causes less soft tissue damage; it does not invade the rib cage, nor does it require a chest drain. $5,13,14$

When compared to posterolateral techniques, the minimally invasive lateral retropleural approach makes better visualization of the nerve structures and more efficient ventral decompression of the spinal cord possible, with less damage to the soft parts. In the correction of deformities, it is able to effectively achieve stretching and/or resection of the anterior spine, through its intervertebral discs and vertebral bodies. 5,13,14 Because it causes less postoperative pain, less hospitalization time with early rehabilitations is observed among operated patients. ${ }^{14}$

Retropleural access can be indicated in the treatment of different spinal disorders, such as degenerative diseases, deformities, trauma, tumors, and infections. Less invasive surgical approaches for neurological decompression and interbody fusion have become popular in recent decades and are being applied to the treatment of degenerative conditions. The T12-L1 level is the most commonly used to treat adult deformity, in multi-level surgeries that seek sagittal and coronal alignment with less morbidity. The minimally invasive lateral approach can also be used as part of an isolated anterior procedure when there is sufficient stability to avert the need for an anterior-posterior approach. ${ }^{9-11}$

The technique proved to be viable in preliminary studies performed on cadavers 5 and subsequently in patients for the treatment of various conditions that affect the thoracolumbar junction, including the use of interbody spacers and instrumentation materials, such as plates and screws. ${ }^{5,10-12}$

Yu et al., used surgical navigation, reporting lower levels of radiation than those who used fluoroscopy. ${ }^{12}$
Uribe et al., Park et al., and Scheufler et al. reported, respectively, mean blood loss of $460 \mathrm{ml}, 374 \mathrm{ml}$, and $280 \mathrm{ml}$; mean surgical time of 240 minutes, 124 minutes, and 163 minutes; and mean hospitalization time of 4.5 days, 3,5 days, and 7.4 days. Patients with tumors, fractures, and degenerative diseases were treated. Images obtained during the postoperative period showed adequate decompression of nerve structures, good deformity correction, and satisfactory positioning of the interbody spacer and instrumentation. ${ }^{5}$

Scheufler et al. also presented favorable clinical results, with significant reduction in morbidity and pain after surgery, early hospital discharge, and less postoperative immobility. ${ }^{14}$

The technique used by this Service was similar to those applied by Uribe et al., ${ }^{5}$ Park et al., ${ }^{10}$ Scheufler et al., ${ }^{11}$ Patel et al., ${ }^{13}$ Payer et al., ${ }^{14}$ and Yen et al. ${ }^{16}$ Yu et al. ${ }^{12}$ differed from the previous ones by using intraoperative computed tomography and navigation. Shi et al., ${ }^{15}$ in turn, conducted a prospective randomized study with two different groups of patients, one of them submitted to retropleural access and the other transdiaphragmatic access, preserving the costal insertion of the diaphragm. When compared, Patel et al. ${ }^{13}$ and Yen et al. ${ }^{16}$ observed mean estimated bleeding rates between $200 \mathrm{ml}$ and $214 \mathrm{ml}$, with hospitalization times of 4.1 and 5.3 days, respectively. Shi et al., ${ }^{15}$ when performing transdiaphragmatic access, observed estimated bleeding of $652 \mathrm{ml}$, with a surgical time similar to that described by Payer et al., ${ }^{14}$ namely 2.9 hours versus 3 hours, respectively.

There are many possible complications that can result from the use of the open technique, including intense pain (caused by the extent of the incision, especially due to intercostal neuralgia) ${ }^{12,15-18}$ and injury to the parietal and pulmonary pleurae, which may lead to the need to use a chest tube, which makes the surgery more morbid and elevates the risk of respiratory tract infections. In the group presented by Shi et al. ${ }^{5}$ that underwent transdiaphragmatic access, twenty cases of pulmonary infection, 17 of atelectasis, 18 of encapsulated pleural effusion, and eight cases of paralytic ileus were identified. In the initial experience of this service, one patient evolved with pleural effusion and pneumonia in the immediate postoperative period requiring hospitalization, chest drainage, and antibiotic therapy, but without the need for ventilatory support.

The experience of a group of authors corresponds to 15 cases. Our results regarding the improvement of the analog scale for pain (VAS), complications, and hospitalization time were comparable to the findings from one of the largest series using thoracoscopic access conducted by Anand and Regan, ${ }^{18}$ as well as to the findings of Payer et al., ${ }^{14}$ and Yen et al., ${ }^{16}$

\section{CONCLUSION}

The minimally invasive lateral retropleural approach to the thoracolumbar junction with the application of an expandable tubular retractor was described step-by-step in this article, highlighting the concepts and critical points of its technical execution, such as preoperative planning, access to the retropleural plane and orthogonal approach for adequate discectomy and/or corpectomy and posterior placement of the implant. The technique is shown to be promising and safe in treating several spinal diseases, despite the complex and challenging local anatomy, and offers unquestionable advantages when the high morbidity rates associated with the traditional access are considered. The results of the first experience of the service proved favorable for the technique. It was not possible, however, to make an objective comparative evaluation between minimally invasive and open techniques in terms of the superiority of radiographic results of one over the other, which will require new, larger studies.

Conflicts of interest: Cristiano: Nuvasive consultant - All other authors declare no potential conflict of interest related to this article. 
CONTRIBUTION OF THE AUTHORS: Each author made significant individual contributions to this manuscript. CMM, FMMF, AOA and MLB performed the surgeries, collected the data, reviewed the literature, and reviewed the final version of the article.

\section{REFERENCES}

1. Sun JC, Wang JR, Luo T, Jin XN, Ma R, Luo BE, et al. Surgical Incision and approach in the thoracolumbar extreme lateral interbody fusion surgery. Spine (Phila Pa 1976). 2016:41(4):E186-90.

2. Dakwar E, Cardona RF, Smith DA, Uribe JS. Early outcomes and safety of the minimally invasive, lateral retroperitoneal transpsoas approach for adult degenerative scoliosis. Neurosurg Focus. 2010;28(3):E8

3. Smith WD, Dakwar E, Le TV, Christian G, Serrano S, Uribe JS. Minimally invasive surgery for traumatic spinal pathologies - A mini-open, lateral approach in the thoracic and lumbar spine. Spine (Phila Pa 1976). 2010;35(26 Suppl):S338-46.

4. Uribe JS, Dakwar E, Le TV, Christian G, Serrano S, Smith WD. Minimally invasive surgery treatment for thoracic spine tumor removal: a mini-open, lateral approach. Spine (Phila Pa 1976). 2010;35(26 Suppl):S347-54.

5. Uribe JS, Dakwar E, Cardona RF, Vale FL. Minimally invasive lateral retropleural thoracolumbar approach: cadaveric feasibility study and report of 4 clinical cases. Neurosurgery. 2011:68(1 Suppl Operative):32-9.

6. Dakwar E, Ahmadian A, Uribe JS. The anatomical relationship of the diaphragm to the thoracolumbar junction during the minimally invasive lateral extracoelomic (retropleural/ retroperitoneal) approach. J Neurosurg Spine. 2012;16(4):359-64.

7. Baaj AA, Papadimitriou K, Amin AG, Kretzer RM, Wolinsky JP, Gokaslan ZL. Surgical anatomy of the diaphragm in the anterolateral approach to the spine. J Spinal Disord Tech. 2014;27(4):220-3

8. Mundis GM, Akbarnia BA, Phillips FM. Adult deformity correction through minimally invasive lateral approach techniques. Spine (Phila Pa 1976). 2010;35(26 Suppl):S312-21.

9. Isaacs RE, Hyde J, Goodrich JA, Rodgers WB, Phillips FM. A prospective, nonrandomized, multicenter evaluation of extreme lateral interbody fusion for the treatment of adult degenerative scoliosis. Spine (Phila Pa 1976). 2010;35(26 Suppl):S322-30.

10. Park MS, Deukmedjian AR, Uribe JS. Minimally Invasive Anterolateral Corpectomy for Spinal Tumors. Neurosurg Clin N Am. 2014;25(2):317-25.

11. Scheufler KM. Technique and clinical results of minimally invasive reconstruction and stabilization of the thoracic and thoracolumbar spine with expandable cages and ventrolateral plate fixation. Neurosurgery. 2007:61(4):798-809.

12. Yu JYH, Fridley J, Gokaslan Z, Telfeian A, Oyelese AA. Minimally invasive thoracolumbar corpectomy and stabilization for unstable burst fractures using intraoperative computed tomography and computer-assisted spinal navigation. World Neurosurg. 2019;122:e1266-74

13. Patel NP, Birch BD, DeMent SE, Elbert GA. The mini-open anterolateral approach for degenerative thoracolumbar disease. Clin Neurol Neurosurg. 2010;112(10):853-7.

14. Payer $M$, Sottas $C$. Mini-open anterior approach for corpectomy in the thoracolumbar spine. Surg Neurol. 2008;69(1):25-31.

15. Shi J, Yue X, Niu N, Zhao C, Qiu H, Wang Z. Application of a modified thoracoabdominal approach that avoids cutting open the costal portion of diaphragm during anterior thoracolumbar spine surgery. Eur Spine J. 2017;26(7):1852-61.

16. Yen CP, Uribe JS. Mini-open Lateral Retropleural Approach for Symptomatic Thoracic Disk Herniations. Clin Spine Surg. 2018;31(1):14-21.

17. Wewel JT, Uribe JS. Retropleural Thoracic Approach. Neurosurg Clin N Am. 2020;31(1):43-8.

18. Bordon G, Girona SB. Assessment of related surgical complications of minimally invasive retropleural approach to the thoraco-lumbar spine. Rev Esp Cir Ortop Traumatol. 2019;63(3):209-16. 